\title{
THE PSYCHOLOGICAL REVIEW.
}

\section{A STUDY OF THE EARLY USE OF SELF- WORDS BY A CHILD.}

BY PROFESSOR CHARIES H. COOLEY,

\section{University of Michigan.}

It has long seemed to me that the first use by children of names for the self - particularly the pronouns ' I,' ' me,' ' my' and ' mine' - was a matter of peculiar interest. Here, if anywhere, I thought, we may hope to make out what the self-idea actually is, in its naive and comparatively simple form, in the form under which it functions in the every-day relations of life. I was especially attracted by the interest of the matter for sociology - as throwing light on the question how far and in what sense the self-idea is a social conception - but I suppose it has a bearing on other aspects of psychology, and perhaps on metaphysics.

Having already made some scanty observations in the development of two of my children ${ }^{1}$ I determined, in the case of a third, to give especial attention to this point and make as full a record as practicable of the use of self-words and whatever seemed to bear upon it, up to the time when they were thoroughly mastered. This determination was not carried out with ideal completeness; but I hope enough observations were made to be of some value.

The record extends from soon after birth until the thirtythird month, when the normal use of self-words seemed to have been acquired. The method was simply that of ordinary observation, with very little defiberate experiment: the idea being to get a view of development under usual conditions.

'See the chapter on 'The Meaning of I' in Human Nature and the Social Order, 1902. 
The observations relate chiefly to a period of about a year, beginning with the twentieth month, during which the child ' learned to talk.' Some scattered notes, however, are given from an earlier period, as being possibly suggestive of the growth of the self-idea before it becomes articulate. The matter given, with the exception of that in brackets, consists exclusively of verbatim transcripts of nates made at the time the phenomena were observed. It must be said, however, regarding the theoretical suggestions thrown out in the notes, that I had some theories to start with.

I proceed to state more particularly some of the questions in relation to which the observations seem to me to be of interest.

The General Problem. - This may be said to be, "How is 'I' learned and what does it mean?"

It is evident that the learning of ' $I$ ' offers a somewhat peculiar problem. The reason is the apparent impossibility of learning its proper use by direct imitation. As used by other persons it never, apparently, means the same thing as when used by the child. An apple is an apple to all alike, but 'I' is different for every user of the word.

As to what it means; the following, to me at least, are interesting questions. Does it mean the physical self ? If something else, then what? How far, or in what sense is it a social idea? How is the naming of the self-related - as to priority and otherwise - to the naming of other persons? What other names for the self are there, and how are they related to the pronouns of the first person? On all these questions the notes have more or less bearing, which I will try to indicate, in part at least, with the hope of rendering them more interesting and intelligible.

Inarticulate Self-feeling. - The child early manifests a feeling akin to pride in control over her own body and over material objects. (See observations on the fourth month, twentieth day, on 10-16, $11-22,15-17$.)

This extends, nearly or quite as early, to the sense of power over other persons. (3-I ?, 3-4?, 3-6?, 7-1, II-22, I3-28, 158, I5-I7, 15-24.)

The Correct Understanding of ' $I$ ' and 'You' when Used 
by Others. - This was achieved by the middle of the nineteenth month. (19-14, 19-16, 19-19.) It is to be noted that this does not involve the same problem as the correct use of ' $I$,' since that word may be understood as a mere objective name for the other person.

Imitative Use of ' $I$ ' Phrases, Apparently Without a Sense of the Subjective Reference, or Indeed any Discrimination of ' $I$ ' from the Rest of the Phrase. - This is clearly the first step in the actual use of the word, and is a phenomenon that continues, more or less, long after the correct use is acquired. It began, in this case, early in the twenty-second month. (22-7, $22-12,23-1$ ? , 23-I7, 23-23, 24-3, 24-6, 24-7, 24-8, 24-9, 24-IO, 24-I 2, 24-I 5, et seq.)

Suggestions as to How the True or Subjective Meaning of ' $I$ ' is Grasped. - This is in some ways the most searching question of all. My answer is that the child gradually comes to notice the indications of self-feeling (the emphasis, the appropriative actions, etc.) accompanying the use of ' $\mathrm{I}$,' ' $\mathrm{me}$ ' and ' my' by others. These indications awaken his own self-feeling, already existing in an inarticulate form. He sympathizes with them and reproduces them in his own use of these words. They thus come to stand for a self-assertive feeling or attitude, for self-will and appropriation. This view is reinforced by noticing how responsive the child is to stress, and how readily she understands and reproduces exclamations and other emphatic words. (14-9, 21-13,23-5, 23-19, 23-21, 23-23, 24-6, 24-10, $24-15,25-4,25-5,25-6,25-13,25-21,26-2,26-13,26-16$, 26-17, 26-28.)

Examples of the Earliest Correct Use of ' $I$ ' and Other Pronouns of the First Person.-(23-1, 23-5, 23-12, 23-21, 23-22, 23-23, 23-30, 24-4, 24-6, 24-12, 24-I 5, 24-16, 24-18, 24-20, 24-2I, et seq.)

Does ' $I$ ' Mean Primarily the Visible or Tangible Body? To this, if I correctly interpret the observations, the answer must be, No. 'I' means primarily a self-assertive feeling, linked with action or emphasis expressive of the same. The earliest examples connect it with the assertion of sensation, of action, of service and of appropriation ('I see mama,' 'my 
toast,' 'I make go,' 'I carry pillow,' 'I get it for you,' ' my mama,' 'I go play sand-pile,' 'I got two flowers,' etc.).

Moreover there is another name which comes into use about the same time as ' $I$ ' and means primarily the physical body. This name, in this case, was ' baby,' and was apparently learned by direct imitation and association, like the name of any other visible object. The shadow on the wall and the reflection in the looking-glass play an important part here. It is noteworthy how comparatively late self-feeling seems to connect itself with these images. They are much less interesting at first than the shadows or reflections of other persons. (19-16, 19-23, 20-25, 2 I-I $3,23-2,23-7,23-I 4,23-19,23-25,23-28,23-3$ I, 26-2, 26-28.)

In what Sense is ' $I$ ' a Social Conception? - The answer to this is apparently something as follows: ' $I$ ' is social in that the very essence of it is the assertion of self-will in a social medium of which the speaker is conscious.

A sympathetic study of the early use of the word will, I think, make this quite plain. ' $I$ ' is addressed to an audience - usually with some emphasis - and its purpose is to impress upon that audience the power ('I make go'), the wish ('I go play sand-pile '), the claim ('my mama'), the service ('I get it for you') of the speaker. Its use in solitude would be inconceivable (though the audience may, of course, be imaginary).

To put it otherwise, ' $I$ ' is a differentiation in a vague body of personal ideas which is either self-consciousness or social consciousness, as you please to look at it. In the use of ' $I$ ' and of names for other people, the ego and alter phases of this consciousness become explicit.

Others are Named Before the Self. - This was clearly true in the present case. $(14-26,15-8,18-30,19-16,19-18,19-23$, 2I-13, 24-20.)

Other Names for the Self. - It is well known that little children frequently use a name for themselves that is directly imitated from others, like the name of any other object. In this case as already noted the first name of this sort was 'baby.' It did not precede ' $I$ ' and gradually merge into it as the child be came more sophisticated (many have the impression that this is 
what takes place), but it arose simultaneously, so nearly as could be ascertained, with the pronoun form. (23-19, et seq.)

'Baby' meant at first her reflection in the glass, her shadow on the wall, her physical person. (19-16, 19-23, 20-25, 23-7, 23-I4, 23-I9, 23-28, 23-3r.) It was soon, however, applied to action and possession. (23-25, 24-15, 24-20, 24-21, et seq.)

It gained on the pronouns and for some weeks was the commonest name for the self, though it never entirely supplanted 'I.' (24-2I, 24-25, 25-2, 25-I4, 25-16.) The pronouns, however, mended their pace, gained a lead, and gradually displaced 'baby' altogether. (25-2I, et seq., to the end.)

'She,' another self-name acquired by direct imitation -i.e., by hearing people say 'she needs a clean dress' and the likewas used as early as $\mathbf{2 3 - 2}$ and is noted as common towards the end of the twenty-sixth month. It continues so for about two months, then diminishes, and is discontinued about the end of the thirty-second month. $(26-22, e t$ seq., to the end.)

The use of 'you' for 'I' by direct imitation ( $e . g$., 'I carry you,' meaning 'you carry me') is first recorded at the end of the twenty-third month, and remained common well into the twentyseventh. I think, however, that this was never so definitely and deliberately used as a self-name as was 'she' - perhaps because ' you' was already understood in its true sense. Its use for ' $I$,' though very common, was mostly confined to its occurrence in phrases which were repeated as wholes.

The observations follow.

Second month, Ixth day. $B$ cries for her bottle, and cries in apparent anger when it is taken away from her. Sometimes cries when laid down.

$3^{-1}$. $B$, two months old, already cries to be taken up, or in protest against being laid down, also for her bottle. [This and some of the following observations are given as possible manifestations of an early sense of appropriation, such as later underlies the use of self-words. Those cases where the thing appropriated is not a material object but the attentions of other people are especially pertinent. They seem to be the beginnings of that desire for control over others, for social power, which plays so large a part in the mature self.] 
3-4. Apparently she has a sense of being neglected, which makes her angry. If $I$ let her simply lie in my lap she screams angrily, but picking her up and changing her position mollifies her. It is not pain that makes her 'mad.' If so she already appropriates attentions that do not minister appreciably to her comfort, has a social self. [Perhaps mere discomfort sufficiently accounts for the crying.]

3-6. $B$, laid down on the bed yesterday, cried hard, with intervals of rest, for twenty minutes or more. $E$ finally took her up. She was 'mad.'

4-20. $B$ has a look of power and triumph - eyes open and lips pressed together - in grasping and shaking a napkin-ring, or my beard.

7-I. $B$, six months old, clearly appropriates $E$ 's attentions. She is used to them and has the my-feeling about them. She cries 'mad' when she is laid down on the bed and $E$ goes away.

ro-16. What pride $B$ shows in her face when she stands on her own legs, holding on to the chair-back, or makes the water splash in her tub. She has put forth will, has intended and achieved, and her look shows the sense of power.

I I-22. $B$, nearly one year old, is playing with a large envelope. She pulls it away and grunts angrily when I take hold of it. When she is standing on a chair and I am holding her by the dress she will sometimes try to remove my hand from the latter [i.e., resents assistance]. When $E$ or I have been with her and attempt to go out of the room she generally cries.

I3-2. $B$ now knows 'your ear' $[i, e$, will touch her own ear when she hears this expression]. She has had.her hand directed to her ear, also watched herself feel of it in the glass. For a week or two she has known 'ear' as applied to others.

I3-3. She does not remember 'your ear' to-day. She imitates a good deal by ear, little by eye. A hissing sound she repeats when she does not [immediately] hear it made.

I3-9. She distinguishes vaguely between 'ear' and 'your ear,'-not, I think, with any [true] sense of 'your.' 'Your ear' is merely a name for certain sensations.

13-28. $B$ loves to walk holding my finger. She screams determinedly when I sit down, or when $R$ or $M$ is offered as a 
substitute. She will also lead me to the front door and insist on having it opened and going out. In general she is capable of forming clear wishes and insisting on gratifying them.

Her 'self-consciousness' or 'showing-off' idea is not yet very distinct, though $E$ thinks she is often conscious of spectators.

14-9. $E$ was feeding baby alternately with herself orange at the table and saying with some emphasis 'now it's $m y$ turn.' So the word might easily be learned. $\quad[I . e$., the self-assertive emphasis and feeling on the word 'my' might be learned along with the sound, and the child thus acquire an inkling of the true meaning of the word as the name of a self-assertive attitude.]

14-26. $B$ seems to take no interest in her reflection in the glass. Has she become used to it as a picture and not sophisticated enough to care for it as herself?

I 5-8, $B$ has, I think, no self-consciousness regarding her reflection in the mirror. She will smile at it as at another baby, or look puzzled; but there is nothing that suggests selfrecognition.

She will sometimes pluck my sleeve or foot to get a look [from me] when $I$ am reading.

15-17. $B$ is very vigorously appropriative; screams when she is not allowed her own way, as when she wants to sit in her mother's lap or to have a plaything. Is said to have objected the other day to Emily (still younger) touching her playthings.

r5-24. $B$ seems to be jealous, or at least fretfully appropriative, of other people. She is not well; her teeth irritate her and her digestion is out of order. She will not let any one else touch her mother when the latter is holding her, but will grunt complainingly and push the offender away. So when I had her at $T$ 's she objected to their baby touching me. She expresses the idea 'mine' very clearly.

15-27. $B$ is very fond of being talked to-more and more evidently so for some weeks past. She makes noises in reply, chiefly a soft ah, apparently intentional.

15-30. $B$ has been indisposed for some weeks, 'out of sorts.' She frequently objects to being looked at, especially by her mother, and will complain and push the other's face about 
till it looks away. Perhaps she feels the anxiety [expressed in the face] but I think it is a 'sense of other persons,' a feeling of disturbance and claim.

r7-. She imitates dog, cat, squirrel, horse, whistle of nipple, squeaking of finger on tub, children crying, etc., bluejay, rushing of water, piano, pounding of hammer, tearing of paper, many human sounds. The more familiar used as signs.

I8-2. $B$, seeing a picture of a man showing his teeth - a tooth-powder advertisement I believe-shut her jaws and opened her mouth in imitation. This is the first conscious facial imitation I have noticed. She watches herself in the glass occasionally.

18-30. $B$ shows no (reflected) self-consciousness, nothing like vanity or affectation. She seems to attach no particular meaning [?] to her own name, though often called by it. She betrays no interest in her own shadow on the wall, though she recognizes 'mama,' 'papa' and occasionally $R$ [on the wall].

I9-I4. $B$ apparently understands 'my' and possibly 'me.' With four of us sitting about she will correctly put her finger on ' your' (i. e., her own) eye, nose, ear, tooth, etc.; 'my,' ' $R$ 's,' 'mama's,' ' papa's.'

19-16. $B$ seems to have no reflective self-consciousness. She has and uses names for papa, mama, etc., none for herself. It is doubtful if she understands any name for herself, though she knows the meaning of 'your' as applied to nose, ear, etc. She recognized and named our shadows on the wall before showing any interest in her own. She knows the latter now as 'baby,' but seems to regard it merely as an external object. [She understood but did not say 'baby' as referring to her shadow.]

I9-18. B's words are used when she sees the object, or when some one mentions it, not deliberately to ask for something. 'Mama' she has only begun to use in this way within a few days, $i . e$, calling out when she sees $E$.

19-19. 'Other.' She understands this perfectly; 'other eye,' etc. When I said ' Where is the other mouth?', she pointed to $R$ 's. She does not know ' his' or ' her' though clear on 'my' and 'your.' 
I9-23. $B$, as $E$ and I agree, has no reflective idea of herself at all. She knows the reflection in the glass and the shadow on the wall as 'baby' but seems to view them merely as external objects, without self-feeling. She is beginning to call the rest of us by name, but has no name for herself.

$B$ has none of the evident 'self-consciousness' that $M$ had much earlier, none of the 'perfect little actress' tricks. She is learning to talk rapidly.

20-25. $B$ when asked 'Who is this?' (touching her on the chest) answered, 'baby.' This is the first time she has been observed to name herself.

2I-I3. I notice that $B$ constantly hears ' $m y$ ' and 'mine' used emphatically and addressed to herself. For instance, at table her mother, feeding her, will say of the food ' no, this is mine,' etc.

The children try to teach her to say 'baby,' but as yet she does not do so at all of her own accord, though she says ' mama,' 'papa,' and ' Leila ' freely.

22-7. $B$ now says 'I see' or 'I do' imitatively, with no real sense of the meaning of ' $I$,' after $E$ or the children. To-day she said 'two ear' the first observed case of her making a sentence, limiting one word by another.

22-12. $B$ has been taught to say 'I see Yacky,' 'I see papa,' etc. She seems to have some inkling of the meaning, and will say 'I see cocky' to the picture. It is all imitative and probably involves no true sense of ' $I$.'

23-I. $B$ was playing by herself in the room with $E$ to-day, and began to say ' my mama' over and over, meditatively. Presently she changed to 'my papa,' then 'my hanky.' She said it very plainly. It is not apparent why she connected it [i.e., the word ' $m y$ '] with these words. Doubtful also whether she had any sense of the meaning.

23-2. She still has no word for herself. We call her 'baby; but she never uses it. . . . If you say 'Where's baby?' or 'Where's $B$ ?' she says 'Here she is.' [This last phrase probably a mere echo.]

23-4. It is hard to tell whether $B$ appropriates her reflection [in the glass] or not. Sometimes she seems indifferent, some- 
times a little 'strange,' as if it were some child she did not know. She was much amused and delighted when she saw it with its clothes off. Never, apparently, does she seem 'selfconscious' about it, like an older girl 'seeing how she looks.'

23-5. $E$ says 'I see baby.' $B$ says [in answer]' I see mama' not 'I see baby.' She even seems, sometimes, to emphasize 'I.' Of herself she said 'I see $O$ ' [the letter]. She knows 'I see' as an exclamation of seeing; but whether she feels the self-assertion in it I can't say.

23-7. $B$ understands that 'baby' means herself when someone else speaks it (probably also 'Mary Elizabeth' and ' Mary') but she will seldom or never say, it herself. Touch $E$ and ask 'Who's this?' she says 'mama': touch me, 'papa'; touch her, she remains silent or grunts. She will not repeat the word 'baby' after you in any connection, though she will almost anything else. She does not seem embarrassed or self-conscious or puzzled; merely prefers not to use the word. It is hard to interpret it, I can only suppose some slight embarrassment. Formerly she did say it occasionally, now not at all.

23-12. $E$ thought she said ' my toast' this morning, but could not say whether she really meant it. It is easy to see, however, how she can learn 'my.'

23-14. Proofs from photographer. $B$ will point to her own picture when we say 'Where is baby?' but seems quite indifferent to it and will not name it when we point to it. On the other hand she eagerly points out all the rest of us.

23-17. $B$ is perfectly able to say 'my' as indeed almost anything else, and occasionally does so imitatively. Just now $E$ said 'Where's my shoe?' and $B$ repeated ' my shoe.'

23-19. This evening $B$ overcame her reluctance to name herself. $E$ touched herself saying 'Who's this?' $B$ said 'mama.' Then she touched $B$, repeating the question. $B$ answered 'baby' with a smile - almost a laugh. She has often refused to do this, though she knows the word 'baby' very well.

I notice that $B$-and doubtless all children, vide $R$ quickly notice and imitate any word used with strong emphasis, reproducing the emphasis as exactly as possible. To-day $E$ lost her patience over the push-cart and said 'the deuce' half under 
her breath. A few minutes later $B$ began saying it, repeating it many times. This may bear on the learning of ' $m y$ ' and ' I,' being words often brought out with strong feeling. ' $\mathrm{My}$ ' might be used at first as a mere exclamation associated with controversy.

23-2x. $B$ was calling her ball ' come ball,' then 'mama.' $E$ said 'don't call me, I'm not a ball.' Immediately she began to say ' Don't call you, don't call you.'

$\mathcal{B}$ this morning was pulling the thread from some of the spools on $E$ 's screen, making the spools revolve. She said 'Makee go, makee go.' Presently she hesitated and said 'I makee go, I makee go' quite clearly, kind of singing it to herself. She has never used ' my' understandingly nor called herself by any other name [?]. N. B. Just as I was saying this in her presence she remarked ' $\mathrm{My}$ papa' as if to confute me.

[The above is the first fairly clear case of the deliberate use of ' $I$ ' with a true sense of its meaning.]

I have little doubt that $B$ uses 'I' with a sense of appropriative feeling which she has perceived to accompany its use by other children. $M$, for instance, is constantly saying 'I'll do it,' 'I'll show you,' etc.

23-22. $E$, "Where is the marble? Do you see the marble?" $B$, 'I see marbly' (though she didn't).

23-23. 'Me,' first use of the word. $B$ was reaching for her pillow. $E$ was present but at a little distance. $B$ said, as if to herself, 'gi't to me, gi't to me.' Then, as if pleased with the sound of the word, she said several times 'me, me, me.' As $E$ says, she probably hears the children use this phrase and stores it up as a whole. 'Give it to me' is associated in her mind with appropriative activities observed in others.

Although $B$ is apparently beginning to use 'me,' ' I' and ' my,' she does not by any means employ them wherever they would be in place. Thus $E$ says, 'Ask Rutger to put you up.' She goes and says 'Ask Yacky put up,' a mere repetition.

Just now $B$ suddenly began tugging at a piece of tape attached to some work $E$ was doing, crying emphatically, ' $\mathrm{My}$, my.' She did this for a few seconds and then turned to something else. She never [?] used the word before except by mere echo. 
23-25. Said 'Baby's shoe' without suggestion. First [possessive] use of this kind of name for herself.

[The reader will note that the use of the subjective names for the self-'I,' 'me' and 'my'-begins almost simultaneously with objective names like 'baby.']

23-26. To-day $B$ was riding in her cart and put her hand on the wheel. [She had been scolded for doing this.] She exclaimed 'Why, baby' in a tone of reproof, just as she says. 'Why, Yacky' to $R$.

23-28. [By her mother.] Playing with silver cup. I said 'Who is in there?' seeing the reflection. She looked in carefully and said 'Mama' (I was looking in too), 'baby.' I said 'See the blue dress.' She put her hand on her own dress. Presently she put her hand on her head (not looking in the cup) and said with a queer little look, 'My baby.' As when a familiar idea looms up in a new light, not a smile.

23-30. $B$ is learning to talk very rapidly. She will look at a picture of two girls and say 'Lilly girl walk-walk. Other lilly girl walk-walk.' When she falls down she says 'You'll fall,' and then 'Hop up.' [Echoes, of course, of what has been said to her on such occasions.]

This afternoon as $B$ was lying on the bed she said, apropos of nothing, 'This is me, this is me.' Apparently there could be no mistake about the words, but I am not sure what she meant.

23-3I. She was interested in her shadow on the wall this morning, putting her finger on it and saying, 'Baby, baby.' She has known this for months and got it directly, as the name of the shadow.

She seldom if ever calls herself 'baby.' [The cases previously secorded remained for a time almost unique.]

24-3. $B$ still refuses to name her reflection in the glass usually; though occasionally she will say 'Baby.' She seems a very little conscious about it now.

'Where's my comb?' $B$ said this many times yesterday imitatively. It began in her taking $E^{\prime} s$ comb, who said 'Where's my comb?'

24-4. Sitting on the piano this evening $B$ said two or three 
tumes, with emphasis, apropos of nothing obvious, 'Dis my.' Don't know just what she meant.

24-6. $B$ was playing with her pillow up stairs and talking to herself. She said 'I carry pillow' several times = taking it from the box to the chair, etc.

$E$ dropped the book and said 'There goes our book.' $B$ said ' There goes $m y-y$ (emphatic) book.'

When $B$ wants to be carried she says 'I carry,' an echo of 'Shall I carry you?,' or she says 'Takey you, takey you,' echoing 'Shall I take you?' These are words, total symbols: she does not analyze them.

24-7. Just now she was sitting on my lap. She reached toward $E$. 'What do you want?' 'Shee-e you' = apparently 'Come and see you.' [It was still doubtful whether she had acquired the proper use of 'you.']

$B$ occasionally repeats sentences beginning with ' $I$ ' that she has heard ; e.g., 'I guess it's so.'

24-8. $B$ says 'I'll carry you' when she wants to be carried; an echo of course. 'Yacky tease you' (me). [On the other hand 'you' is sometimes used correctly.] $B$, crying, says 'I want you,' apparently her mother.

24-9. At breakfast $B$ says 'Come see me' to the stuffed duckling. She probably learns such phrases as wholes $=$ 'I will take it' or the like.

$M$ said 'I wish baby could go out doors.' For some minutes thereafter she $[B]$ said at intervals 'I wish out doors.'

24-10. She constantly repeats [after someone else] phrases containing 'my,' e. g., 'Don't touch my (sewing-machine) wheel.' She seems to put more emphasis on 'my,' dwelling on it as if it impressed her.

$B$ shows great aptitude for exclamations - doubtless because they are uttered with great emphasis. She has recently used 'Deuce,' 'Gee Whiz,' ‘Oh My,' 'Oh Dear,' 'Why Yacky.' N. B. ' $\mathrm{My}$ ' and ' $\mathrm{I}$ ' are perhaps learned on nearly the same principle, $i$.e., an expression of vivid feeling.

February 19, when Leila went away, $B$ could scarcely if at all put two words together. She had a few single words besides our names; $e$. g., 'street-car.' Now, not two months 
later, she uses words quite freely and gets off such sentences as this (probably copied, but not immediately) 'Where my nut, squirly says' (no attempt to give exact sound).

24-12. She just said 'Where's my ball?' (We had been playing with it.)

She says 'Take you,' ' I carry you,' meaning, apparently, 'You take me,' etc.

She just said 'Eat my spoon.' (She had a spoon in her mouth.) Can't tell how she understood it.

The use of 'you' for ' $I$ ' is very frequent.

24-13. $B$, looking for $E$, said 'Hello, baby' [echoing what her mother might say when found].

24-15. She says 'I take you'(You take me), 'Come and see me (you) and many similar phrases. But she perhaps does not identify ' $m e$ ' with anyone else. They are mere [imitative] formulæ describing action. 'I carry you, shovely,' she says to the shovel. To the candle 'I takey you.' [These last are examples of how ' I' may be correctly used in describing action before its special meaning is discriminated.]

She dropped the harp and wanting $R$ to get it, said ' Want that, Yacky?' He did not move : then she got down, saying, 'I get it for you.' This last phrase is one she hears her mother use, and probably means for her merely ' pick it up' or the like - perhaps with the idea of self-action.

To-day she said 'Baby wash hands,' meaning she wanted to wash. She does this [uses 'baby' to name herself] occasionally now, not often, but apparently more often than she did.

'Want you' = 'I don't want you.' N. B. 'You' here seems used correctly.

24-16. She just called out as she was going up stairs, ' Going to find my dolly.'

But this [use of 'my'] is rare. Did she mean possibly 'Margaret's'?

24-18. She caressed $E$ just now and said softly and deliberately, 'This my mama.' And immediately put her finger to her face and said 'baby.' It looked like an effort of self-social consciousness. This is rare if not unique.

24-20. $B$ has occasionally used 'I,' 'my,' 'me' and 'baby' 
apparently as names for herself (as previously noted) but at this date she uses none of them commonly. When she wants a thing she simply names it without personal pronouns. She has no name for herself in regular use. Though she names the rest of us constantly.

$B$ 's imagination is developing. We have told her the wolf and piggy story, and she thinks about it. She came up to $E$ yesterday and said 'Wolf say puff ! puff!' To-day she seemed to think the wolf might be down the register, saying, 'Wolf down there? No, no, wolf.'

At dinner to-night she asked for potato by saying 'Baby some tato' but did not use this form again. She also said 'I takey pillow' when she picked it up to bring to me. This evening again, 'Baby lie down.'

24-2I. She seems to have begun the free use of 'baby' as a name for herself. The first thing this morning she said ' Baby want matches' and 'Baby's shoes.'

To-day she picked up a handful of grass and said, softly as if to herself, 'I gotty grass.' Then $E$ picked up a handful and she said 'You gotty grass.'

She now uses both the pronominal and 'baby' form. I am curious to see which will prevail.

[Between the last and the succeeding.] This morning $B$ said 'Baby's leg.' Immediately after she said 'I sit down.'

24-24. My for me. 'My some tato.'

24-25. 'I' and 'baby' together. 'Baby go getty hook. I gotty hook. Gi' it to mama.' She seemed to be dramatizing, speaking to baby. She uses 'baby' a good deal, 'I ' rarely.

You. 'You takee book too,' meaning herself.

24-26. My. 'Takee my hand and pull.'

25-2. Looking for a picture of a baby in the magazine she said 'Baby, where are you?' Probably imitative? [The correct use of 'you' was still uncertain. 'You' mostly meant herself.]

$B$ uses 'baby' now a good deal. Also, occasionally, ' $I$ ' as just now 'I take the rooster.' She still uses phrases like 'I take you' (= You take me).

'I ' used rightly a good deal: 'I get this ball.' Have not 
noticed ' my' recently. $E$ says she occasionally says ' Take my hand.'

25-4. Although she uses 'I' correctly at times she almost always (quite?) uses phrases she might take bodily from others - as 'I'll get the carriage,' etc. I incline to think she learns these as wholes.

$B$ wanted the knife. $E$ said emphatically, 'My knife.' About fifteen minutes later $B$ said ' Want that $m y$ knife.' She took it and repeated 'My knife.' [This is perhaps suggestive as to how ' $m y$ ' becomes associated with the expression and act of claim.]

Mixing ' $I$ ' and 'you' (as self-names). 'Mama carry you (me). I go play sand-pile.' Also to her doll-carriage, 'Stay there. I'll go pick stones.'

25-5. She uses ' $I$ ' in sentences of action rather frequently - perhaps a dozen times a day, e. g., 'I getty cushion.'

25-6. 'Have that my knife. $M y$ knife.' [See 25-4.] Immediately after she said 'Papa help you' (me). She doesn't use ' $m$ ' ' in its right sense, if at all.

25-7. 'Baby, I.' Sometimes she unites them : Baby I got two, mama.' She uses either quite freely in this sense.

Long sentence. 'When Yah-Yah ring bell ding-a-ling-aling, then come dinner.'

25-8. 'Where's the pillow?' 'I'll get it for you.'

25-13. She says 'I got two flowers.' Is very fond of 'I got two - ' Last evening she was saying 'My Margy' and 'My papa.' I never heard her use ' $m y$ ' in altercation. [This refers to a theory I had that the first personal pronouns, especially ' $m y$ ' might be learned in disputes over possession.]

25-14. She uses 'baby' now a good deal. ' ['I,' 'my' and ' me' rarely.] Will these be lost?

25-16. $E$ thinks that $B$ frequently says 'Come see me,' etc. It is often hard to tell whether she says 'me' or 'baby,' she has come to slur the latter so.

'Margy, come see me baby.'

25-2I. $M$ said, 'I want some bread.' $B, ' I$ want bread.' [The stress seems to show a sense of the self-assertive meaning of ' I.'] 
25-2I. The use of ' $I$ ' seems to be gaining rapidly on 'baby.' The former is now, perhaps, the more common.

[Additional examples of the correct use of ' $I$ ' and ' me' are omitted as superfluous.]

[Between the last and the succeeding.] 'Mine,' first use. She was talking to herself, making-believe finding things and holding them out. ' Want necktie ; here's mine ; here's mama's.'

26-I. 'I won't.' Said reflectively, not controversially, this morning when asked to come up stairs. [An echo from other children?]

26-2. I-phrases. She uses many which she seems to learn as wholes - 'I don't know,' 'I want - ,' 'I won't,' ' Come see me,' 'Wake me up.' From these she probably gets the I-idea by elimination. $[I, e$. , the rest of the sentence varies but the pronoun remains constantly associated with the expression of will, the self-attitude.]

She has at this date no notion of calling her body ' $I$,' apparently.

Looking at the photograph she says 'There's baby,' never 'That is I' or 'me.' But when we ask 'Where are you?' she said, with some hesitation, 'There's baby.' (But, on further experiment, this is uncertain.) In answer to 'Where am I?,' however, she named [pointed out in the picture] the speaker.

26-4. Taking a picture from my hand she said 'That's mine.'

26-6. My. Although she sometimes uses it correctly she also uses it incorrectly. $E . g$. , 'Mama go get my [your] lapboard,' 'Take my [your] leg up.'

She never, I think, says 'your,' 'her' or 'his.' (Except your $=m y$, by direct imitation.)

She uses 'me' with more emphasis now.

She said twice to-day 'That's mine.'

26-II. She still says 'I carry you,' much run together, for ' take me up.'

Not only does she still say 'I carry you 'for 'You carry me,' but in many other phrases as 'You want cake.' Often she will use 'You,' ' I' and 'baby' in quick succession to mean herself. 26-I3. Quickness of children in applying language. It is 
amazing, hardly to be fully realized or explained by adults. They are constantly bringing out very aptly some expression they have heard only a few times. Thus to-day $B$ said to $R$ 'Ring off' when he was teasing her. [Current slang for ' cease.']

26-16. $R$ was threatening to take away a necklace. She almost screamed 'Dat mine.' Speaking of her dress she said 'That's my dress; that's mine; that's $b a b y$ 's' all in the same sentence. [The gradual increase of appropriative emphasis on the self-words is notable.]

26-I7. Saying 'My book' with great emphasis, at times almost a scream, when threatened with dispossession by $R$. [Compare 25-13.]

26-18. Emphatic 'you.' ' You go get the ball.'

26-21. 'Herself.' ' Baby hurt herself' she said to-day when she fell down.

26-22. 'She' for self. Is common; $e . g$., 'She does not want to go to bed.' Imitative of some one's remark about her. [This form became very conspicuous about this time.]

26-24. 'She.' To-day she has used this more than ' $I$ ' or 'baby.'

26-28. $E$, 'This is mama' (pointing to $B$ ); 'This is baby' (pointing to herself). $B$, 'No, mine, baby.' [This seems to be the first definite application of a self-pronoun to the physical person.]

27-2. Although she uses 'I,' ' me,' 'my' and 'mine' freely and vigorously she still uses such phrases as 'Mama wants to carry you.' (= I want mama to carry me.)

'We don't want papa,' she said to-day. [First recorded use of 'We.']

27-8. 'I don't want to bite you.' (= You don't want to bite me.)

She uses right and wrong expressions with great freedom and indifference. 'She,' 'baby,' ' I,' ' you,' may each mean herself.

27-9. 'I want to take a walk with me' (you).

27-14. She uses 'she' for 'I' a good deal; but 'I' equally or more. Also 'baby.' She is fond of saying 'I think' or 
'She thinks.' Sometimes she uses this form, "She says she wants two dollies.'

27-25. $B$ still uses ' $I$,' 'baby' and 'she' interchangeably. She is beginning to say 'Mary Liffit' [Mary Elizabeth] also. 28-8. She varies for emphasis. 'I like cake! She likes cake! Baby likes cake!' in quick succession.

'That's yours, Margaret, and that's me's.'

28-27. 'I,' 'baby,' 'she.' $B$ still uses all three for herself. I think she tends to use 'baby' rather more for ' $m e$ ' than for 'I.' 'She' is perhaps somewhat diminishing.

29-26. I notice only an occasional use of 'she' and 'baby' now; also that ' $I$ ' and 'mine' are used with more mastery and gusto.

30-2. Heard her use 'she' [for I] but it is rare.

30-12. $E$ says that $B$ still uses 'she' and 'baby' a good deal, though less than she used to.

30-27. $B$ still uses 'she' quite often, though 'I' and 'me' are much more usual. Sometimes she gets queer combinations - as 'me are.'

$3^{I-1}$. She just now said "Baby going to dance 'se'f" [herself].

3I-9. B has learned to know $T$. To-day she accidentally made one with her blocks. 'Come see my $T$ ' she exclaimed. Then she made many more, quite excited, crying ' $I$ did it,' etc.

$3^{2-26}$. Some peculiarities in pronouns. "Yes we am-. Huh! 'we am' that's a funny way to talk" [self-criticism]. 'Let I see it.' 'She's name is Binks.' I and she are often. used in the objective case.

33-5. We note that $B$ no longer uses 'she' for 'I.' She has gradually dropped it. ${ }^{1}$

${ }^{1}$ The MS. of this article was received on August I, I908. - ED. 